\title{
Using Large-Scale Assessments to Evaluate the Effectiveness of School Library Programs in California
}

\author{
William W. TARR, JR. \\ LAUSD/IFL Science Fellow, Institute for Learning, \\ University of Pittsburgh and the Los Angeles Unified School District \\ United States \\ Stacy L. SINCLAIR-TARR \\ Education Consultant \\ United States
}

\begin{abstract}
This California study examined the relationship between the presence of school libraries, as defined by credentialed staffing, and student achievement, as measured by both criterionreferenced and norm-referenced assessments in both English-language arts and mathematics. Using the California School Characteristics Index to compare 4,022 schools with similar demographics at Grades 4, 7, and 10, both positive and negative statistically significant relationships were found between the presence of a school library and student achievement at Grades 4 and 7. There were no statistically significant positive relationships found at Grade 10. These findings do not support previous studies that used different methods of comparing schools with similar demographics. Also unlike previous studies, the overall effect sizes of the positive relationships were small, the average being an increase in student achievement of $2 \%$. Factors within the school library at Grades 4 and 7 were also examined, and both positive and negative statistically significant relationships to student achievement were found.
\end{abstract}

\section{Introduction}

This study was designed to examine whether a relationship exists between school libraries and student achievement in California. We will begin with a short background including a summary of the problem and the purpose for our research, a synopsis of related research, and the study's findings. We will then discuss conclusions from this study, impacts and implications on previous research, the study's limitations, and implications for future research.

\section{Background}

Federal support for the education of low-achieving children has been an integral part of funding public education in the United States for over thirty years through the Title I provision of the Elementary and Secondary Education Act of 1965 (High Stakes: Testing for Tracking, Promotion, and Graduation, 1999). This funding resulted from a series of global events that linked student achievement with national defense and an understanding that a certain level of education is needed for the future success of the United States. Almost as soon as the legislation was completed, it was determined that 
large-scale assessments should be put in place to evaluate educational programs to determine whether this influx of economic support has a positive impact on student achievement (The National Defense Education Act, Interview \# 4, 2003).

A large-scale assessment tool, the National Assessment of Educational Progress (NAEP), was developed as a common measure to compare student achievement across states to determine how well programs were meeting identified goals. Over 30 years of testing, it has been determined that although funding for K-12 education continues to rise, there has been little significant rise in student achievement as measured by NAEP, with almost $70 \%$ of students continuing to score below the proficient level (The Nations Report Card, 2003).

States currently fund their K-12 education programs primarily through local means, with federal monies comprising approximately $7 \%$ of a state's overall education budget in 1990, rising to approximately 10\% by 2003 (Sonnenberg, 2004, p. iii). With recent economic challenges and the resulting decrease in state revenue, states have been looking for ways to streamline their spending in all areas, including education.

In an effort to increase student achievement in the United States, new federal legislation, the No Child Left Behind Act (NCLB), increased accountability measures for states that choose to receive federal funding by requiring them to develop their own content standards and assessments aligned to those standards. This legislation requires that states receiving federal funds for K-12 education examine the performance of students on state's standards, using state assessments, and ensure that all students, regardless of their ethnicity, economic status, or gender, score at a proficient level (as defined by the states) by 2014 (Elementary and Secondary Education Act, 2001).

\section{Problem}

Given the increased focus on accountability by the federal government, and the increased pressure locally to streamline budgets, schools, districts, and states are looking for ways to examine the effectiveness of school programs to determine which to maintain and which to change or eliminate. As pointed out by Rodney, Lance, and Hamilton-Pennell (2002), the standards-based education reform movement, of which this legislation is a driving force, moves educators to focus on what students have learned (proficiencies or outcomes) rather than on what is taught (curriculum and pedagogy materials). This outcome-based emphasis has created a need to develop quantitative processes to determine the effectiveness of educational programs. States, districts, and schools now define student achievement in terms of specific content students should know and be able to do (standards) and develop assessments to track the proficiency of student mastery to these standards. When used properly, large-scale, external assessments such as those used by California, have been established as valid and reliable in the aggregate for measuring student achievement (AERA, 1999).

California uses two large-scale testing instruments to measure student achievement. The California Standards Tests (CSTs) are criterion-referenced tests 
designed to measure student achievement of the California academic content standards. The California Achievement Test, 6th Edition Survey (CAT-6) is a nationally normreferenced test designed to compare student achievement in California with a broader, nationwide student population. Both test instruments are designed to provide information on student achievement and are components of California's Standardized Testing and Reporting Program (STAR). However, comparisons of school scores must also take into consideration the many differences in the characteristics of schools across the State (e.g. comparisons between schools in the wealthiest and poorest communities would raise many questions in terms of the validity of results). The School Characteristics Index (SCI) is the tool developed by the California Department of Education to adjust for these student demographics and school staffing differences. This tool is used to inform the ranking of schools within the state and is used by the California accountability system, called the Academic Performance Index (recently revised to align with the federal requirements of the NCLB Act).

This Academic Performance Index (API) includes a system of ranking schools called the Similar Schools Ranking (SSR) that is based on student achievement and demographics data to determine the success of a school's program, while taking into consideration factors including socio-economic status, English fluency, ethnicity, staffing, multi-track and year-round programs, and teacher credentialing. The SSR equates these student and staff factors through the School Characteristics Index (SCI) formula so that schools with similar challenges are ranked with each other. Then, student achievement data from the CSTs and CAT-6, as well as other state assessments (e.g., California High School Exit Exam, English fluency, special education testing) are weighted to determine schools' API in an effort to identify which schools have a stronger overall program.

At the local level, programs that help to increase a school's API tend to be given funding priority due to the pressures for increasing student achievement. If school library programs in California can show they support student achievement as demonstrated by an increasing API, these programs will be valued not only for their intrinsic worth but also as valuable tools for teachers and administrators in the effort to increase student achievement.

Seminal studies in Alaska, Colorado, Florida, Iowa, Minnesota, New Mexico, North Carolina, Oregon, Pennsylvania, and Texas have examined the relationship between school library programs and student achievement by correlating survey data on factors within the school library program with increases in student achievement as measured by single year norm-referenced assessments (Baumbach, 2003; Baxter \& Smalley, 2003; Lance et al., 1999; Lance et al., 2001, 2002; Lance et al., 2000a, 2000b; Rodney et al., 2002; Smith, 2001). Each study has shown that a statistically significant and positive relationship exists between the presence of school library programs and increased student achievement. However, these studies have been done in states that, unlike California, do not have grade-level specific standards, and the studies have used norm-referenced test instruments as measures of student achievement, instruments that by their design are not completely aligned to states' specific academic content standards. 
Other seminal studies include national surveys on school libraries from the National Center for Education Statistics (NCES) and work by Miller and Shontz (M. Miller, 2001; M. Miller \& Shontz, 1999; M. L. Miller \& Shontz, 1997, 1998; Snyder \& Hoffman, 2003; J. Williams, 1987; J. Williams \& Chaney, 1998) that have provided valuable information on the characteristics of school library programs from 1949 through the present, data that was used in the student achievement studies listed above.

\section{Purpose}

The purpose of this descriptive, non-experimental study was to determine whether a relationship exists between professionally staffed school libraries and increased student achievement in California using student achievement data for Grade 4 at the elementary level, Grade 7 at the middle school level, and Grade 10 at the high school level. Student achievement was measured using both criterion-referenced (the CSTs) and norm-referenced (the CAT-6) test instruments.

\section{Historical Context}

Until recently, research on school libraries focused exclusively on the structure, funding, and technology available to school library programs as well as studies on the preparation, roles, and responsibilities of professional library staff. However, there have been conflicting perspectives on the value of the school library (Certain, 1917; Drury \& Masters, 1998; Logosa, 1928).

While literature to communicate the value of school libraries has been extensive, it has had no measurable impact on the greater school setting as it has rarely been found in publications that would be read by classroom teachers, administrators, or school board members (Drury \& Masters, 1998; Hartzell, 2002c). Questions were raised as to whether the data collected is appropriate to determine the value of the facility and services, and Todd \& Kuhlthau (2004) suggested that rather than focusing on itemization, the focus should be on outcomes in relation to what students have learned (Lonsdale, 2003).

Research on school libraries and student achievement began in the 1960's with conflicting evidence attributed to a lack of careful control variables (Grover \& Ward, 1979). Studies since 1990 have focused on the roles of the library media teacher, the library collection, technology, and access to the school library in increasing student achievement. These recent studies provided conflicting evidence as to the impact of the school library on student achievement.

More recent studies examining the relationship between student achievement and specific factors within the school library have also had conflicting results in that some studies conclude strong correlations and others conclude weak or no correlations. The most consistent correlations have been made at the elementary and high school level with very few generalizable findings at the middle school level. Where some studies identified specific roles in which the library media teacher had a positive influence on 
student achievement (Lance et al., 2000a; Margolis, 2002), other studies found that the library media teacher can only exert a positive influence if there is a shared vision of their role in the overall instructional program and if their existence does not supplant other educational programs (Brandes, 1986; Lance et al., 2000a, 2000b).

\section{Sources of Data for this Study}

For this study, the school library was defined as "an active, technology-rich learning environment with an array of information resources that combine effective learning and teaching strategies and activities with information access skills" (ALA, 1998, p. 1). In order to determine whether a library program fits this description, data from the California Department of Education's School Library Survey for 2000-2001 and 2001-2002 were used. These surveys are administered in order for schools to examine the efficacy of their expenditures from the prior fiscal year because the fiscal appropriations are delivered to schools at the end of the academic year. Therefore, data collection is not complete until the academic year is completed. For example, the 2000-2001 survey was administered in the 2001-2002 school year since funds were received by the school in May of 2001. The 2001-2002 survey was administered in the 2002-2003 school year since funds were received in May 2002. Table 1 below shows the relationship between School Library Survey year and corresponding STAR test data.

\begin{tabular}{l|l} 
Table 1. Administration of School Library Survey and Corresponding STAR Data \\
\begin{tabular}{l|l} 
California School Library Survey & Corresponding STAR data \\
\hline $2000-2001$ & $2001-2002$ \\
$2001-2002$ & $2002-2003$ \\
\hline
\end{tabular}
\end{tabular}

Since school libraries cannot complete their surveys until the year identified has been completed, this study used the 2002-2003 CST and CAT-6 data since this data reflected the most current implementation of the 2001-2002 funding cycle that included school library purchases and services.

The dependent variable for this study, student achievement, was defined as (a) the aggregate, school wide percentage of Grades 4, 7, and 10 students at the performance levels of proficient and above as measured by the 2002-2003 Englishlanguage arts and mathematics California Standards Tests (CSTs), and (b) the aggregate, school wide percentage of Grades 4, 7, and 10 students at the 50th percentile and above as measured by the 2002-2003 reading, language, and mathematics CAT-6.

The Grades 4 and 7 CSTs in English-language arts include scores from a writing task, and at Grade 10 the mathematics CST used was the end-of-course Geometry Test (the test taken by the largest [25\%] percent of Grade10 students in 2003). The SCI was used as a covariate in each analysis to control for student and staffing demographics 
including socio-economic status, academic calendar, ethnicity, teacher credentialing, and staff seniority.

\section{Key Findings}

What follows is a collection of the key findings from this study. These findings are the basis for conclusions that will be discussed later. Grade 4(Elementary): Statistically Significant Positive Relationships Between School Libraries and Student Achievement

- The presence of a school library is related to an overall $+2 \%$ difference in the number of students at the performance levels of proficient and above on the ELA and mathematics CSTs.

- The presence of a school library is related to the number of students at and above the 50 th percentile on the CAT -6 by $+1.4 \%$ in reading, $+2 \%$ in language, and $+1.6 \%$ in mathematics.

Grade 4 (Elementary): Statistically Significant Positive Relationships Between School Library Services and Student Achievement

- A school library program of curriculum-integrated skills instruction is related to a $+2 \%$ difference in the number of students at the performance levels of proficient and above on the ELA CST.

- The greater the number of library books, based on the numeric spans in the California School Library Survey, is related to a $+.0003 \%$ difference in the number of students at the performance levels of proficient and above on the ELA CST.

- The greater the average number of hours a school library is open per week is related to $\mathrm{a}+.2 \%$ difference in the number of students at the performance levels of proficient and above on the mathematics CSTs.

- Broader opportunities for access to a school library (including before school, during class, during breaks, during lunch, after school, afternoons, evenings, weekends and summer school) are related to a $+.1 \%$ difference in the number of students at the performance levels of proficient and above on the mathematics CST.

- Greater varieties of technology (including automated library catalogs, automated library circulation, Internet access, electronic access to full text periodicals, video collections, and DVD or laser disc collections) are related to a $+1.7 \%$ difference in the number of students at the performance levels of proficient and above on the mathematics CST.

- The availability of a video collection in the school library is related to a $+3.4 \%$ difference in the number of students at the performance levels of proficient and above on the mathematics CST. 
Grade 4 (Elementary): Statistically Significant Negative Relationships Between School Library Services and Student Achievement

- A school library that plans or conducts teacher workshops is related to a $-2.3 \%$ difference in the number of students at the performance levels of proficient and above on the ELA CST.

- A school library providing information about new resources is related to a $-5.5 \%$ difference in the number of students at the performance levels of proficient and above on the ELA CST. 
- The greater the number of classified hours worked is related to a $-.1 \%$ difference in the number of students at the performance levels of proficient and above on the ELA CST.

- The greater the number of services offered, as identified by the California School Library Survey, is related to a $-.3 \%$ difference in the number of students at the performance levels of proficient and above on the mathematics CST.

\section{Grade 7 (Middle School): Statistically Significant Positive Relationships Between School Libraries and Student Achievement}

- The presence of a school library is related to an overall $+3 \%$ difference in the number of students at the performance levels of proficient and above on the ELA and mathematics CSTs.

- The presence of a school library is related to an overall $+1.4 \%$ difference in the number of students at and above the 50th percentile on the CAT-6 in mathematics.

\section{Grade 7 (Middle School): Statistically Significant Negative Relationships} Between School Libraries and Student Achievement

- The presence of a school library is related to an overall -.8\% difference in the number of students at and above the 50th percentile on the CAT-6 in reading.

\section{Grade 7 (Middle School): Statistically Significant Negative Relationships Between School Library Services and Student Achievement}

- The presence of a video collection is related to a $-2.7 \%$ difference in the number of students at the performance levels of proficient and above on the ELA CST and by a difference of $-1.7 \%$ on the mathematics CST.

- A school library that provides reference assistance to student and teachers is related to a $-8.6 \%$ difference in the number of students at the performance levels of proficient and above on the ELA CST.

- Providing access to the school library in the afternoons is related to a $-3.4 \%$ difference in the number of students at the performance levels of proficient and above on the ELA CST.

\section{Grade 10 (High School): Statistically Significant Negative Relationships Between School Libraries and Student Achievement}

- The presence of a school library is related to an overall -.6\% difference in the number of students at and above the 50th percentile on the CAT- 6 in reading. The 
presence of a school library has no statistically significant relationship to student achievement as measured by the ELA or mathematics CST, or the language or mathematics CAT-6.

\section{Summary of Key Findings}

The results of the relationship between school library programs and student achievement were the same at the elementary and high school level using the Englishlanguage arts or math CST as well as using the language, reading, and mathematics CAT6. At the middle school level, the relationship between student achievement and school library programs was statistically significant when using both the English-language arts and mathematics CST but was only statistically significant on the mathematics CAT-6. Elementary (Grade 4)

A statistically significant relationship was found between the presence of a school library program and student achievement on all CST and CAT-6 assessments. In examining the factors within the school library program that may account for this relationship, both infrastructure and services were found to have statistical significance. In terms of infrastructure, increased size of the collection, variety of technology resources, and the presence of a video collection had positive statistical significance. In terms of services, access hours, variety of access times, and the availability of skills integrated instruction also had a positive statistical significance. These findings are supported by seminal studies by Baumbach (2003), Baxter \& Smalley (2003), Burgin (2003), D. Williams (2001), Hartzell (2002a), Lance (2000, 2001, 2002), Lonsdale (2003), Margolis (2002), M.L. Miller \& Shontz (1997), Rodney (2002) and Smith (2001).

The following services, however, had a negative statistically significant relationship to student achievement: planning or conducting workshops for teachers, providing information on new resources, and the number of hours worked by classified staff. In combination, it was found that the more services offered, the less likely that student achievement would increase. These findings were not supported by the previous seminal studies.

\section{Middle School (Grade 7)}

A statistically significant positive relationship was found between the presence of a school library program and student achievement on each of the CSTs and the mathematics CAT-6. In examining the factors within the school library that may account for the relationship, no factor or combination of factors were found to have a statistically significant positive relationship to student achievement. The following infrastructure and services were found to have a statistically significant negative relationship: the presence of a video collection, access to school libraries in the afternoon, and services including providing reference assistance to students and teachers. According to D. Williams \& Coles (2001), little generalizable data has been published on middle school libraries and student achievement. Therefore, the lack of support for these findings by previous studies is to be expected. 
In addition, a statistically significant negative relationship was found between school libraries and student achievement on the language and reading scores on the CAT6.

\section{High School (Grade 10)}

No statistically significant relationship between school library programs and student achievement was found on the CSTs or on the language or mathematics sections of the CAT-6. However, a statistically significant negative relationship was found between school library programs and student achievement on the reading portion of the CAT-6. None of these conclusions based on the relationship between high school libraries and student achievement were supported by previous seminal studies.

\section{Assumptions and Limitations of this Study}

This study used the Information Power (ALA \& AECT, 1998) definition of a school library. This definition, supported by California Education Code and requirements for funding under the Library of California Networking Project, requires that a credentialed library media teacher be employed in order for a school library to exist. If, however, a less rigorous definition of a school library program were used, the grouping of schools for this study may be changed with concomitant different results.

This study used publicly available data from the California Department of Education (CDE) with the explicit assumption that all data was valid. In order for schools to be selected for participation in this study, schools responded to at least one of the California School Library Surveys for 2000-2001 or 2001-2002. Schools are required to submit this survey but there is no penalty for not submitting. Those schools included in this study, therefore, were self-selected. In addition, selected schools needed to have an API (with its related SCI), thus eliminating continuation and alternative schools and schools with missing test data.

There are 7,201 K-12 comprehensive public schools in California. There were 4,022 (56\%) of these schools included in this study. Of the 4,353 elementary schools, 2,589 (59.5\%) were included. Of the 1,271 middle schools, 893 (70.3\%) were included. Of the 1,577 comprehensive high schools, 540 (34.2\%) were included. Although the percent of schools used within this study were within acceptable parameters (usually sampling techniques suggest a $10-15 \%$ participation rate), a higher rate of participation would have made the results even more generalizable. The number of schools used in the study $(4,022)$ at all three levels however, far exceeds the number of schools for any previous study found in the literature.

For the purposes of this study, student achievement data were clustered by performance level (proficient and above on the CST, and at and above the $50^{\text {th }}$ percentile on the CAT-6) since individual student achievement scores were not available because of privacy considerations. The use of clustered scores created a skewed distribution of scores which resulted in a smaller than expected standard deviation (Huck, 2000). This skewedness will be discussed in the implications following each conclusion stated below. 


\section{Conclusions and Implications - Elementary and Middle School}

Based on the results of this study, there is a statistically significant increase in student achievement at California elementary and middle schools that have a professionally staffed school library over schools that do not have a professionally staffed school library. Within the elementary school libraries, specific characteristics of their infrastructure and services offered may be responsible for this relationship. Implications

A statistically significant and positive relationship between increased student achievement and the presence of school libraries was found, with a large number of schools included in the study. At the elementary level, 449 schools with school libraries and 2,140 schools without school libraries were examined. At the middle school level, 495 schools with school libraries and 398 schools without school libraries were examined.

Based on the conclusion above, increasing the number of schools with school libraries should result in an increase in student achievement at more schools. The nature of the comparison groups, however, invites the possibility of a Type I error, leading to a conclusion that a statistically significant relationship exists when none is actually present (Vogt, 1999). By adjusting the relationship between the standard error and effect size to compensate for the possibility of a Type I error, the effect of a school library at the elementary or middle school level drops to a gain of $1 \%$ or less on any of the test instruments used. Therefore, while a statistically significant relationship exists between student achievement and school libraries as stated above, it will have to be determined if this significance is practical within the context of program funding decisions. Local districts will need to determine if the impact of the $1 \%$ gain is enough to justify the presence of a school library program. Previous studies that examined effect size, including the Pennsylvania, Colorado, and Oregon studies (Lance 2000a, 2000b, 2001), cited effect sizes between 2-8\% (both extremes cited in the Second Colorado Study (Lance, 2000a). Since this study's effect sizes were markedly smaller, the difference in research methods was examined as a possible reason for the difference.

Previous studies accounted for demographic differences using an Analysis of Variation (ANOVA) process that did not reflect the combined nature of demographic challenges but examined each demographic factor with each school library factor independently. The Analysis of Covariation (ANCOVA) process in this study, however, used the SCI to examine demographics as a combined variable as well as to examine the combined impact of library factors. These differences in methodology and the resulting differences in proportion of variance $\left(r^{2}\right)$ levels may explain the differences in these results and should be considered when making decisions based on the results of this study.

In examining the factors within the school library that may account for the relationship between student achievement and school libraries, the same test for Type I errors was considered. When adjusted for this possibility, each statistically significant factor (negative and positive) retained less than a $1 \%$ effect size on student achievement. 
It is inconclusive, therefore, which factors within the school library, if any, have a practical impact on increasing student achievement.

The identification of factors within the school library was developed through a series of observational studies by Miller \& Shontz (1996, 1997, 1998, 1999, 2001) and Lance (1993, 1999, 2000a, 2000b, 2001a, 2001b, 2002a, 2002b). By examining successful school library programs, a common set of factors present in these programs was developed. It was suggested that having 17 or more of these factors resulted in a successful library program. This study used the list of common factors (as identified on the California School Library Survey) to determine the relationship, if any, of these factors to student achievement. Given the information above, it could be concluded that either the factors identified are not those which make a successful library program, or that there are few if any successful library programs in California. With either conclusion there are implications for the community of library media teachers as well as for school sites and school districts. The library community should closely examine the factors within the library that demonstrated an $r^{2}$ of 0.25 or greater (proportion of variance) for increasing student achievement, as well as a statistical significance, to see how these infrastructure and services can be strengthened to support increasing student achievement. As former Secretary of Education, Rod Paige said,

The times call for everyone in education to accept leadership in improving the quality of education offered to every child... More time needs to be spent looking at what students are learning and how teachers can be more effective at their jobs. (Scherer, 2004, p. 21).

Library media teachers in California may need to reflect on how they complete the California School Library Survey. Since the identification of factors within the library are self-selected, the staff may believe a program characteristic is in place when this may not be the case. Rather than having the library media teacher complete the survey, it might be suggested that someone else at the school site (administration, Leadership Team, etc.) assist in completing the survey to verify the program components identified.

Additionally, library media teachers may need to become more knowledgeable about the academic content standards, core instructional curriculum, and standardized assessments facing students at their school in order to focus the library program on the services most needed to support increased student achievement. Although program components may be in place, these components may not be focused on the foundational knowledge that students need in order to affect their achievement scores. If the library program is supplemental rather than a part of the core instructional program, this may account for the results of this study. Some researchers feel that the personal characteristics of the library media teacher and staff have the strongest impact on the resulting program (Loertscher, 2000; Stripling, 1995; D. Williams, Wavell, \& Coles, 2001). Staffing characteristics and the ability to collaborate and impact the greater school program, therefore, shouldbe examined.

School sites and districts should consider the role of the school library and the library media teacher in the context of the goals for the school. Currently, there is not a 
common vision about the role of the library media teacher in the overall school program. This lack of a common vision may derive from the lack of shared professional literature on the role of the school library as well as a lack of vision about the role of the library program within the greater instructional setting (Hartzell, 2002b; Brandes, 1986). This confusion is furthered by library media teachers who fulfill, or intend to fulfill, only a few facets of their role (Villency Small, 2001). As a result, all stakeholders should have a clear understanding and input into the role and services the school library offers so that the program can be leveraged for increased student achievement.

This would ensure that the goals of the school library are in alignment with the goals of the school, and become an integral component of the instructional program by focusing on increased student achievement. Purchases of equipment and books should support the greater instructional program, and services should complement and strengthen classroom-based instructional initiatives. As supported by studies done by Lance (2002), the school library has its greatest impact when it supports the general education program rather than supplants it.

\section{Conclusions and Implications - High School}

There is no statistically significant increase in student achievement at California high schools that have a professionally staffed school library over schools that do not have a professionally staffed school library.

\section{Implications}

At Grade 10, the Geometry CST was selected to represent mathematics achievement because it was the course with the greatest percent of students enrolled (25\%). Although some school districts do not require students to take math each year during high school, based on the California sequence of leveled courses in mathematics, the goal in California is for students in Grade 10 to take Algebra II after completing Geometry in Grade 9 (although few districts are currently meeting this goal as evidenced by course enrollment and the 2003 test administration). The implication of the choice to use the scores of Grade 10 students on the Geometry CST is that this data does not include those students who are currently meeting the state's goals for course sequencing. Therefore, the achievement results included in this study may not include a fully representative sample of students in mathematics. As a consequence, the results of this part of the study, student mathematics achievement, may not be generalizable

The conclusions of this study suggest that library media teachers, as well as schools and districts, should examine their library programs carefully. Since this study did not find evidence to support a relationship between high school libraries and student achievement, it will be imperative that library media teachers and school library staff look for evidence within their individual programs to demonstrate how their program supports student achievement and to identify where barriers to students' success exist. With the loss of library media teachers across California due to staffing reductions, there are fewer models of successful programs for existing libraries to replicate. There may be opportunities to provide invaluable leadership within and across schools, bridging the 
isolation classroom teachers can feel by library media teachers providing expertise, curriculum-based resources, and services.

\section{Conclusions and Implications - Criterion and Norm-referenced Tests}

The two test instruments used in this study-the California Standards Tests (CSTs) in English-language arts and mathematics and the California Achievement Test, 6th Edition Survey (CAT-6) in reading, language, and mathematics-provided similar information on the relationship between school libraries and student achievement. Implications

Because the two test instruments provided similar information on student achievement, a similarly designed analysis of school programs in the future can be completed using the CST or the CAT-6. It may not be necessary to use both tests as measurements of student achievement.

In addition, the results from this study can be compared to seminal studies that used only norm-reference test results. Therefore, the compounding evidence that this study provides the library science field can add to the generalizability of conclusions.

\section{Further Research}

The results of this study offer many areas in which further research can be explored. With the national move toward a standards-based education and assessment system, schools are asked to focus on what students have learned (proficiencies or outcomes) rather than on what is taught (coverage of content) (Burgin et al., 2003; Lance et al., 2002). This changes the conversation from what the teacher does to what the student has gained. Results of this study can be used to ask school library media teachers to critically examine their programs and to reconsider what they are teaching and the services they offer.

Questions arise as to why a statistically significant relationship was found only at the elementary and middle school levels,. With a smaller percentage of library media teachers to the overall number of school sites at the elementary level, the results may be attributed to the culture of schools who choose to fund a library media teacher or to the skills of these professionals who continually work to be indispensable under the pressure of annual budget cuts. Cultural differences at schools may support or hinder collaboration, changes in program implementation, or re-visioning of the overall program. Future research might examine whether the potential impact of the library media teacher and the overall library program is affected by the number of students or staff to be served, the self-contained versus departmentalization of school programs, or the adjunct duties assigned to library programs (such as the circulation of student textbooks). Although the effect size was small in terms of student achievement on standardized tests, further research on the work of the school library to support student achievement may uncover other untested factors that generally support the importance of school libraries at all levels. 


\section{Closure}

This study raises a number of further questions about capturing the value of a school library and strengthening the school library program. Schools and districts should examine the potential benefit of the school library in increasing student achievement and explore the specific and local barriers to this potential. This includes developing a shared understanding of the role of the school library media teacher within the context of the overall school program and identifying the specific role of this program within the context of curriculum development, classroom and library instruction, assessment, intervention, and enrichment.

When The Crisis in California School Libraries: A Special Study was released in 1986, Brandes depicted the "dismal state" of school staffing and resources. The school library community used the document as a rallying cry for increased funding and support for school programs and was successful with the passage of The California School Library Act of 1998. As this funding diminished, many of the earlier gains in staffing and collection development have slowed or stopped completely.

Because this study indicates that school libraries are not as successful in increasing student achievement as other state studies, it is hoped that this work will be used to energize and refocus the school library community. The results and implications of this survey should not be used as a rationale for closing school libraries or for decreasing funds to these programs. To the contrary, by examining this study, school districts and school library media teachers should increase their commitment to completing the California School Library Survey on an annual basis to ensure that future studies more completely reflect the work of all schools in California. By engaging the many stakeholders of the school in the role and vision for the school library program, its power to engage students and teachers in learning can be more fully realized.

ANCOVA: Analysis of Covariation

\section{Glossary}

ANOVA : Analysis of Variation

API : Academic Performance Index

CAT-6: California Achievement Test, $6^{\text {th }}$ Edition Survey

CDE: California Department of Education

CSTs: California Standards Tests

ELA: English - language arts

ESEA: Elementary and Secondary Education Act

NAEP: National Assessment of Educational Progress

NCES: National Center for Education Statistics

NCLB: No Child Left Behind

SCI: School Characteristics Index

SSR: Similar Schools Ranking

STAR: Standardized Testing and Reporting Program 


\section{References}

AERA. (1999). Standards for educational and psychological testing. Washington D.C.: American Educational Research Association and National Council on Measurement in Education.

ALA \& AECT. (1998). Information power: Building partnerships for learning. Chicago: American Library Association and Association for Educational Communications and Technology.

Baumbach, D. (2003). 3 key findings. Retrieved October 15, 2003, from

Baxter, S. J., \& Smalley, A. W. (2003). Check it out! The results of the school library media program census. Retrieved August 12, 2003, from http://metronet.lib.mn.us/survey/index.cfm

Brandes, B. (1986). The crisis in California school libraries: A special study. Sacramento: California Department of Education.

Burgin, R., Brown Bracy, P., \& Brown, K. (2003). An essential connection: How quality school library media programs improve student achievement in North Carolina. Retrieved October 17, 2003, from http://www.rburgin.com

Certain, C. C. (1917). The high school library. Educational Review, 54, 76-82.

Drury, J., \& Masters, A. (1998). School libraries and the progressive movement: A study of the role of the librarian in implementing progressive education (1900-1957). Englewood, CO: Libraries Unlimited, Inc.

Elementary and Secondary Education Act. (2001).

Grover, R., \& Ward, B. (1979). Research on media and learning: A preliminary report of the CMLEA research Committee. California Media and Library Educators Association (1979), 5-9.

Hartzell, G. (2002a June). Capitalizing on the school library's potential to positively affect student achievement: A sampling of resources for administrators. Paper presented at the Laura Bush Foundation, Washington, DC.

Hartzell, G. (2002b June). What's it take? Paper presented at the White House Conference on School Libraries, Washington, DC.

Hartzell, G. (2002c). Why should principals support school libraries? Retrieved January 14, 2003, from

High stakes: Testing for tracking, promotion, and graduation. (1999). Washington, D.C.: National Academy Press.

Huck, S. W. (2000). Reading statistics and research (3rd ed.). Tennessee: Addison Wesley Longman.

Lance, K. C. (2001). Proof of the power: Recent research on the impact of school library media programs on the academic achievement of U.S. public school students. ERIC Digest, EDO-IR-2001$05,4$.

Lance, K. C., Hamilton-Pennell, C., Rodney, M. L., Petersen, L., \& Sitter, C. (1999). Information empowered: The school librarian as an agent of academic achievement in Alaska schools (case study). Juneau: Alaska State Library. 
Lance, K. C., \& Loertscher, D. V. (2002). Powering achievement: School library media programs make a difference: The evidence mounts (2 ed.). San Jose: Hi Willow Research and Publishing.

Lance, K. C., Rodney, M. J., \& Hamilton-Pennell, C. (2001). Good schools have school librarians: Oregon school librarians collaborate to improve academic achievement: Oregon Educational Media Association.

Lance, K. C., Rodney, M. J., \& Hamilton-Pennell, C. (2002). How school libraries improve outcomes for children: The New Mexico study. Santa Fe, New Mexico: Hi Willow Research and Publishing.

Lance, K. C., Rodney, M. L., \& Hamilton-Pennell, C. (2000a). How school librarians help kids achieve standards: The second Colorado study. Denver: Hi Willow Research and Publishing.

Lance, K. C., Rodney, M. L., \& Hamilton-Pennell, C. (2000b). Measuring up to standards: The impact of school library programs and information literacy in Pennsylvania schools. Greensburg: Pennsylvania Citizens for Better Libraries.

Lance, K. C., Welborn, L., \& Hamilton-Pennell, C. (1993). The impact of school library media centers on academic achievement (case study). Castle Rock: Hi Willow Research and Publishing.

Loertscher, D. V. (2000). Taxonomies of the school library media program (2 ed.). Salt Lake City, UT: Hi Willow Research and Publishing.

Logosa, H. (1928). The high school library: Its function in education. New York: D. Appleton \& Co.

Lonsdale, M. (2003). Impact of school libraries on student achievement: A review of the research. Melbourne: Australian Council for Educational Research.

Margolis, R. (2002). Acing the exam: How can librarians boost students' test scores? School Library Journal(October), 50-52.

Miller, M. (2001). New money old books. School Library Journal, 50-60.

Miller, M., \& Shontz, M. (1999). How do you measure up? Retrieved February 17, 2003, from http://www.cde.ca.gov/library

Miller, M. L., \& Shontz, M. L. (1996). Live wires - "high-tech" media specialists get connected. School Library Journal, 26-32.

Miller, M. L., \& Shontz, M. L. (1997). Small change - expenditures for resources in school library Media centers, FY 1995-96. School Library Journal, 28-37.

Miller, M. L., \& Shontz, M. L. (1998). More services, more staff, more money - a portrait of a high-service library media center. School Library Journal, 28-33.

The National Defense Education Act, Interview \# 4. (2003). Retrieved November 5, 2003, from http://www.senate.gov/artandhistory/history/oral_history/Oral_History_McClure.htm

The Nations Report Card. (2003). Retrieved November 27, 2003, 2003, from

http://www.nces.ed.gov/nationsreportcard/naepdata/ 
Rodney, M. J., Lance, K. C., \& Hamilton-Pennell, C. (2002). Make the connection: Quality school library media programs impact academic achievement in Iowa. Bettendorf, IA: Mississippi Bend Area Education Agency.

Scherer, M. (2004). A call for powerful leaders: A conversation with Rod Paige. Educational Leadership, 61(April), 20-23.

Smith, E. G. (2001). Texas school libraries: Standards, resources, services, and student performance. Austin, TX: Texas State Library and Archives Commission.

Snyder, T. D., \& Hoffman, C. (2003). Digest of education statistics, 2002 (No. NCES 2003-060). Washington, DC: U.S. Department of Education.

Sonnenberg, W. C. (2004). Federal support for education FY 1980 to FY 2003 (No. NCES 2004-026). Washington D.C.: U. S. Department of Education.

Stripling, B. K. (1995). Learning-centered libraries: Implications from research. School Library Media Quarterly, 23(3).

Todd, R. J., \& Kuhlthau, C. C. (2004). Student learning through Ohio school libraries (Report): Ohio Educational Library Media Association.

Villency Small, R. (2001). School librarianship and instructional design: A history intertwined. Englewood, CO: Libraries Unlimited, Inc.

Vogt, W. P. (1999). Dictionary of statistics \& methodology: A nontechnical guide for the social sciences $\left(2{ }^{\text {nd }}\right.$ ed.). Thousand Oaks, CA: SAGE Publications, Inc.

Williams, D., Wavell, C., \& Coles, L. (2001). Impact of school library services on achievement and learning. Arberdeen: Robert Gordon University.

Williams, J. (1987). Statistics of public and private school library media centers, 1985-86 (No. ED284545). Washington DC: US Department of Education.

Williams, J., \& Chaney, B. (1998). School library media centers: 1993-94 (report No. NCES 98-282). Washington D.C.: U.S. Department of Education.

\section{Author Notes}

William Tarr Jr. earned his B.A. degree in Biology and Environmental Ecology from California State University, Northridge, was awarded a W.M. Keck Molecular Biotechnology Fellowship from the California Institute of Technology, an M.A. degree in Educational Administration from California State University, Dominguez Hills and an Ed.D. in Educational Technology from Pepperdine University, California.

Stacy Sinclair Tarr, a National Board Certified Teacher, earned her B.A. in Choreography from Bennington College, Vermont, an M.S. degree in Educational Administration from California State University, Northridge, and an Ed.D. in Educational Technology from Pepperdine University, California. 
Reproduced with permission of the copyright owner. Further reproduction prohibited without permission. 